\title{
Load Capacity of steel arches with shotcrete coating
}

\author{
Pawet Ficek ${ }^{1, *}$, Krzysztof Kuczowicz ${ }^{1}$, Szymon Wróbel $^{1}$, and Marek Rotkegel ${ }^{2}$ \\ ${ }^{1}$ PGG S.A. Piast-Ziemowit coal mine, Bieruń, Poland \\ ${ }^{2}$ The Central Mining Institute (GIG), Katowice, Poland
}

\begin{abstract}
The shotcrete technology (application of a concrete layer) is widely used in coal mines. The applied layer of shotcrete to the underground workings support, changes the load capacity of the entire supporting system (and its elements). The coating of shotcrete is several times cheaper, faster and safer compared to the traditional reconstruction of the roadways replacement of the supports. Appropriate selection of shotcrete parameters will allow applying shotcrete to places previously dedicated for reconstruction, and thus reduce the financial resources consumed in the mines for the reconstruction of underground workings. The article presents a method of testing steel arch supports covered with shotcrete, a station for weighting support section and a test plan.
\end{abstract}

Keywords: shotcrete coating, steel arch supports, underground workings

\section{Introduction}

Underground roadways in polish coal mines are developed mainly with use of steel arch supports made of V-bar sections V29 (29 kilograms per linear meter) and V32 (32 kilograms per linear meter), and recently more often sections V36 (36 kilograms per linear meter) [16].

Manufacturers offer a whole range of different combinations of supports, both in terms of contour [11], their load capacity [1], and the materials used [15.17].

Therefore, the mines are able to choose the appropriate support section due to the purpose of the underground working, the required dimensions, as well as the expected tension from the rock mass and possibly resulting from the suspension of machinery and equipment, and then determine the required spacing of the support sections.

This ability to shape parameters of the steel arch supports is its undoubted advantage. Hence the popularity of this supports in mines in other countries - in China, Turkey [6], Vietnam, Russia [20] and Ukraine [8].

However, when choosing a steel supports, it is necessary to take into account its durability, resulting primarily from the corrosion of steel elements $[10,12,18]$ (sections, clamps, stretchers, steel mesh lining) caused by the aggressiveness of the mine environment $[13,14]$. This is an extremely important factor, especially in the case of excavations with a long service life of up to several or several dozen years.

*Corresponding author: p.ficek@pgg.pl 
Corrosion phenomena particularly affect mines in which water is characterized by considerable aggressiveness. Examples are the Piast and Ziemowit mines [6,7]. Examples of heavily corroded underground roadways supports are shown in the figure 1.

The progressive corrosion of the supports leads to a reduction of its load capacity, and in extreme cases may result even in collapsing. Each time it leads to the exclusion of the underground workings from use and the resulting difficulties, but above all it worsens the level of safety of mining crews.

Such events, fortunately without victims, have occurred several times in recent years in Polish coal mines. An example here may be events from the mines of Halemba, Bielszowice, Bytom III, Piast, Ziemowit [19].
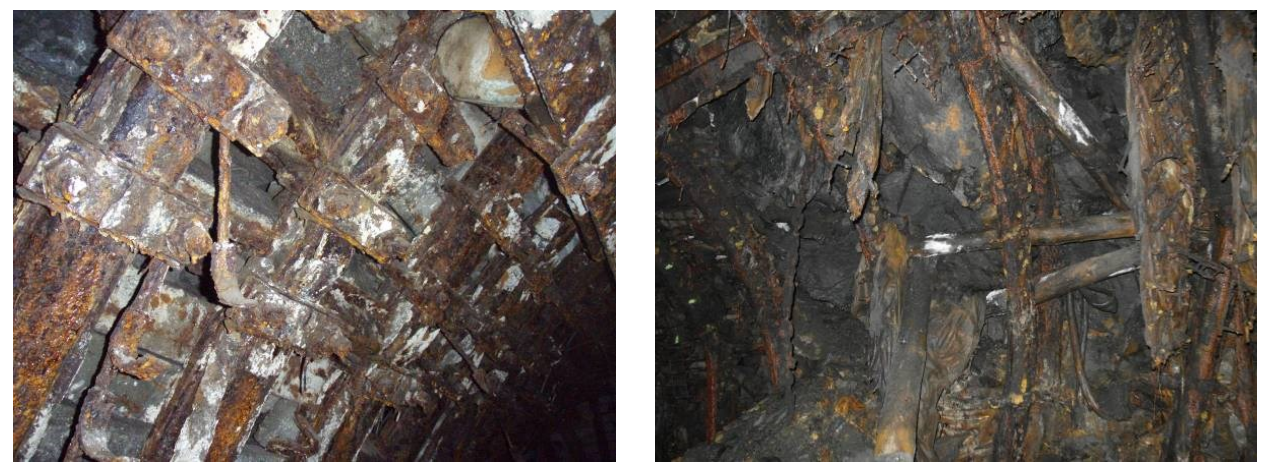

Fig. 1. Corrosion of steel elements (photo M. Rotkegel).

Providing stability and functionality of underground roadway, and thus safety, requires regular inspection including influence of corrosion to steel arch supports [2, 3]. Regular inspection allows to identify places where stability of underground roadway support is endangered and select such places to be reinforced with shotcrete layer.

\section{Shotcrete as reinforcement of corroded steel supports}

The most popular method of reinforcing steel supports and recovering their supporting capacity is covering with shotcrete layer [4], being an alternative of very expensive process of rebuilding the underground roadway [5].

The popularity of shotcrete method results from uncomplicated, fast, inexpensive and safe technology.

Picture no. 2 depicts an example of application of shotcrete in Ziemowit part of PiastZiemowit coal mine.
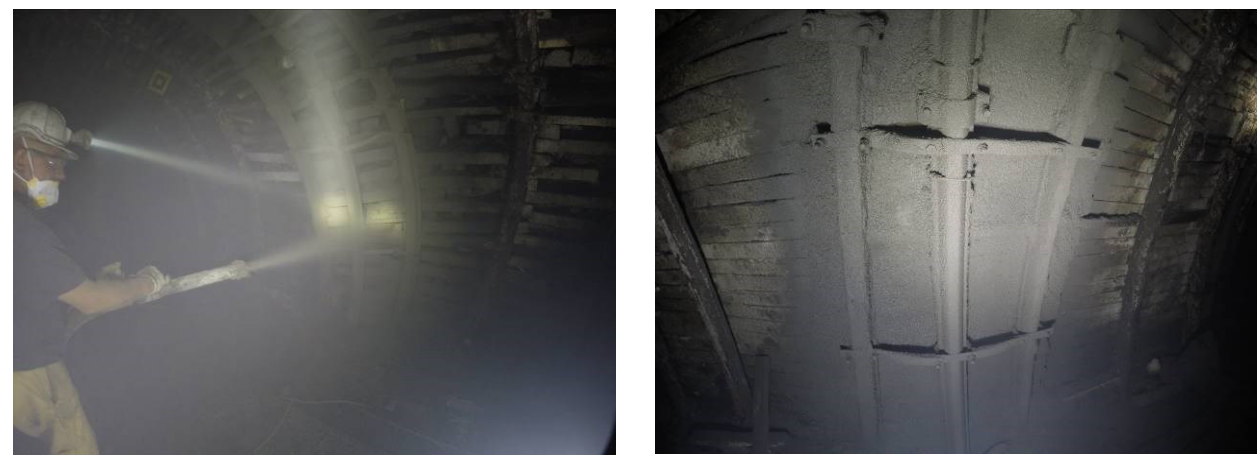

Fig. 2. Applying a shotcrete layer (photo P.Ficek). 
When developing a project to strengthen a corroded supports, the mine can select material with appropriate parameters and determine the thickness of the coating, taking into account the load capacity of the corroded supports.

As part of the research, an attempt was made to determine the state of effort of individual components of the combined supports - steel supports and shotcrete coating. Recognition of stress values supports and shotcrete can be helpful in determining the parameters of the shotcrete coating.

Numerical analysis was performed using the finite element method [9] using the COSMOS / M program [23]. The aim of the study was to determine the effect of a shotcrete coating, changing stress in steel supports. Two models were built for research purposes.

The first model consisted of ŁP8 steel arch support made of V29 section. The second model consisted of $Ł P 8$ steel arch support made of V29 section covered with shotcrete layer. The elements were given material parameters as for steel and concrete. In addition, elements susceptible to the contact of the support with the bottom of the roadway and with the sidewalls have been adopted. Both models were limited to a quarter of the real system due to symmetry.

Appropriate constraints were established on the planes of symmetry of the examined system. The models were supported and loaded in the same way. Calculated per one support section, a load of $400 \mathrm{kN}$ was assumed, which corresponds to loads in the supports before the occurrence of slips of the support clamps. Both systems were loaded in a manner similar to the planned load diagram in underground tests, presented later in the article. Figures 3 and 4 present models prepared for analysis.

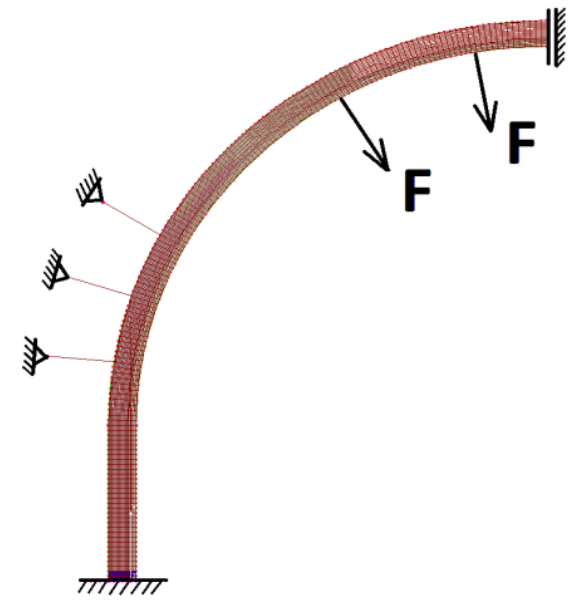

Fig. 3. A complete model prepared for research (F-load).

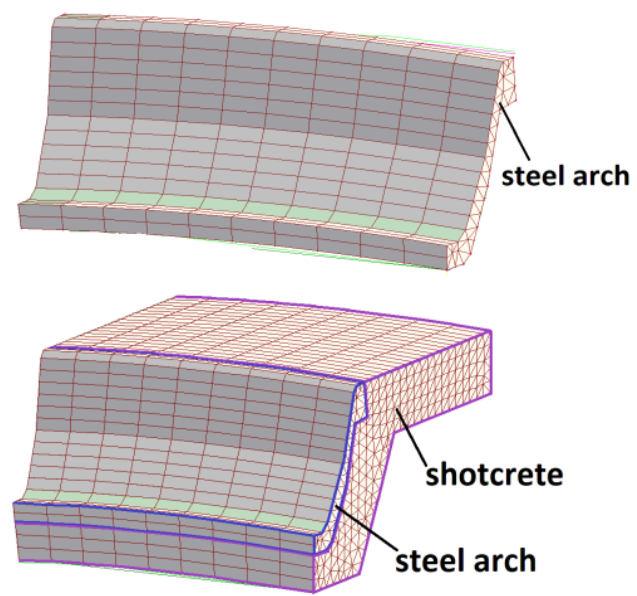

Fig. 4. Model fragments.

As a result of performed calculations, the distribution of reduced stresses in individual model elements were obtained. Figures 5 and 6 present a colored map of reduced stress in the support model. The maximum stress values reach $349.1 \mathrm{MPa}$ and are located in the support vault. 


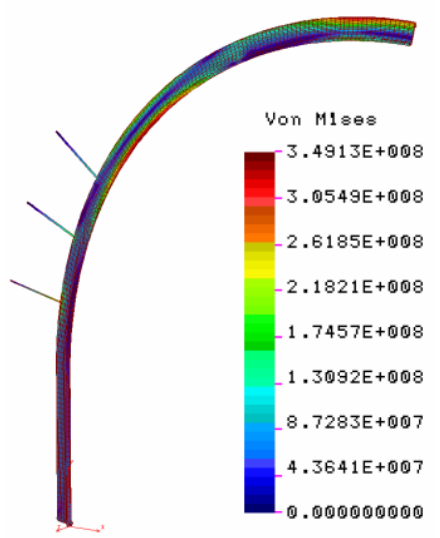

Fig. 5. Distribution of reduced stresses in supports (Stress scale in Pa, deformation scale 2x).

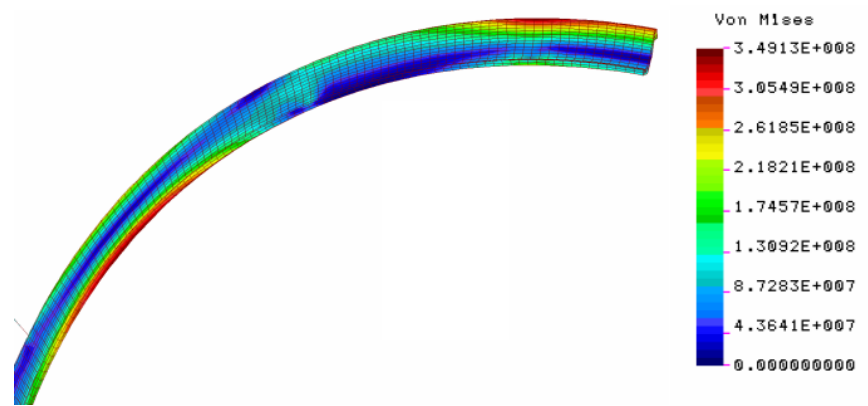

Fig. 6. Distribution of reduced stresses in the canopy of the support (Stress scale in Pa, deformation scale $2 \mathrm{x})$.

However, in the case of supports covered with shotcrete, the maximum stress values in the supports decrease to $46 \%$. Maximum stress values reach $161.9 \mathrm{MPa}$. They are located in the top part of the support. A colored stress map is shown in Figures 7 and 8. In contrast, Figures 9 and 10 show the distribution of reduced stress in the canopy arch and shotcrete.

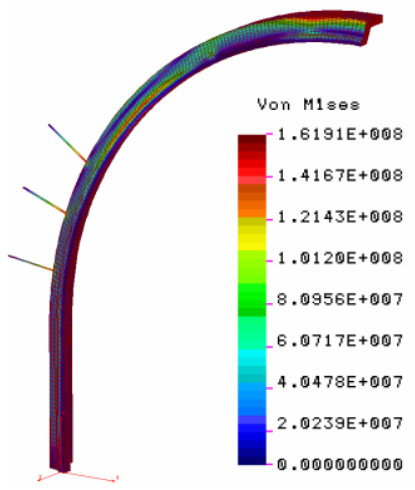

Fig. 7. Distribution of reduced stresses in a model of supports covered with shotcrete (Stress scale in $\mathrm{Pa}$, scale of deformation $2 \mathrm{x}$ ). 


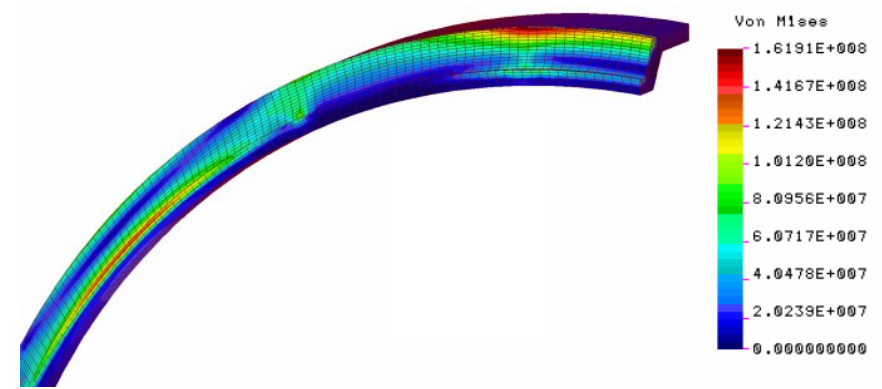

Fig. 8. Distribution of reduced stresses in support canopy covered with shotcrete (stress scale in Pa, scale of deformation $2 \mathrm{x})$.

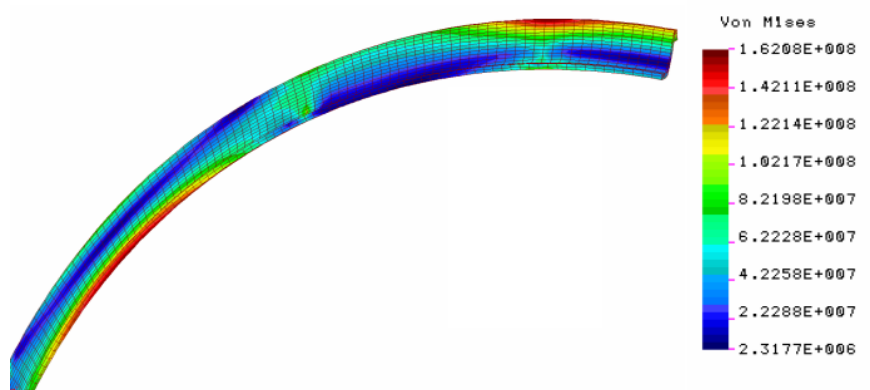

Fig. 9. Distribution of reduced stress in elements of support canopy covered with shotcrete (stress scale in Pa, scale of deformation 2x).

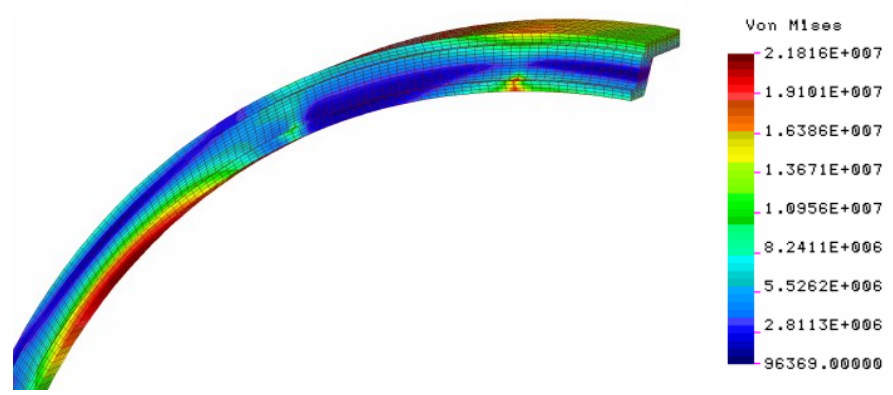

Fig. 10. Distribution of reduced stresses in shotcrete in a model of supports covered with shotcrete (stress scale in Pa, scale of deformation 2x).

As the results of the presented analysis, the use of shotcrete coating significantly reduces the stress in steel supports. These stresses decreased from 349.1 MPa to 161.9 $\mathrm{MPa}$. However, the condition for this is the complete merging of the shotcrete coating with the support sections. The durability of shotcrete is also important here. Under the modeled load conditions in the shotcrete, maximum values of reduced stress were obtained at $21.8 \mathrm{MPa}$.

They are located at the junction of the ceiling and the sidewall. These are compressive stresses and their values do not exceed the compressive strength of shotcrete. Whereas, in the ceiling part of the shotcrete coating, tensile stresses appear of considerable values (about 20 $\mathrm{MPa}$, located at the place of application of the load). Therefore, it is expedient to use dispersed reinforcement of shotcrete using fibers, which increase the tensile strength of the shotcrete. Figure 11 shows the distribution of the main stress in the shotcrete coating. 


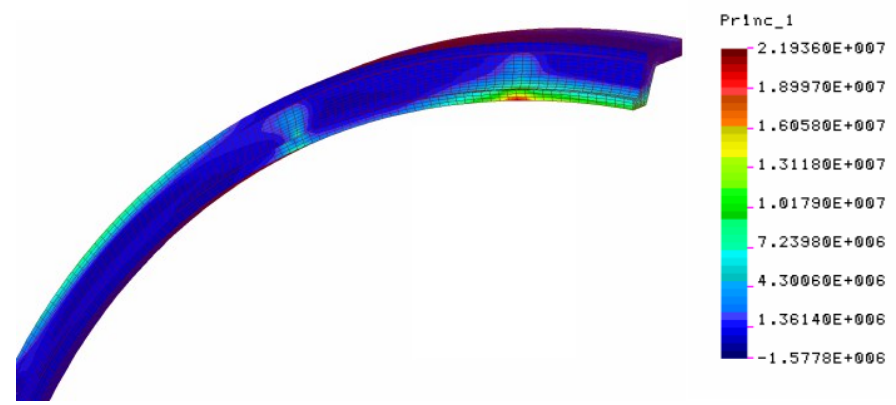

Fig. 11. Main stresses in the shotcrete coating (Stress scale in Pa, scale of deformation $2 \mathrm{x}$, red areas tension zones, blue areas - compression zones).

As shown above, the numerical determination of the required thickness of shotcrete and its parameters is burdened with many simplifications, and the results must be interpreted by experienced mine employees.

However, this standard ignores the effect of filling the empty spaces between reinforced concrete lining, or rock filling, which creates a thicker layer of merged elements than the coating of shotcrete.

In addition, spraying at an angle allows to fill any empty spaces behind the support sections, thus improving their working conditions. These situations are shown in Figures 12 and 13.

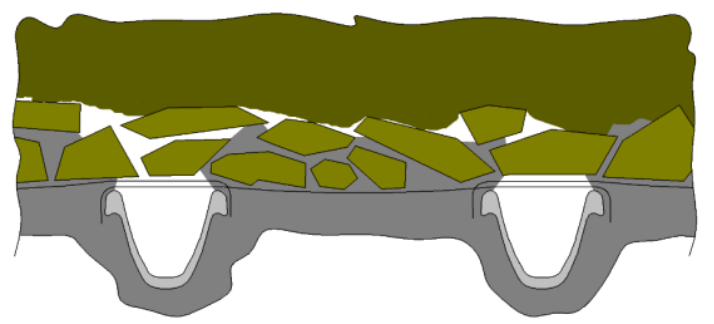

Fig. 12. Merging of rock filling by covering with shotcrete [21].

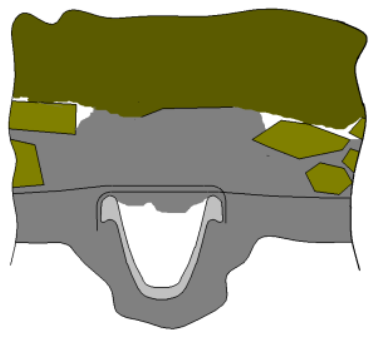

Fig. 13. Filling the empty spaces behind support sections [21].

Due to the fact that the presented standard does not take into account the factors presented above, actions were taken to determine in situ the load capacity of the mixed support made of steel supports covered with shotcrete. The developed research methodology allows to take into account many mechanisms of strengthening the supports by applying shotcrete. 


\section{Testing site}

Determining the load capacity of individual support sections is not a major problem. Such tests are conducted, among others, in the process of certification of supports, in a test stand, in accordance with the provisions of PN-G-15022 [22].

It is also possible to calculate the load capacity analytically [1] or by numerical methods, for example finite element method [9] (FEM, FEA). A much more complicated issue is determining the load capacity of a mixed support - steel support with a layer of shotcrete.

In the laboratory, it is not feasible to conduct such tests, taking into account a merged reinforced concrete lining or a rock filling. Therefore, it was decided to conduct such tests in underground conditions at the Ziemowit mine at the level of - $300 \mathrm{~m}$ below ground level.

A blind roadway located near the shaft, leading to the ventilation dam, was not used for other purposes.

The roadway on the test section was scanned with a 3D Trimble TX5 laser, which allowed to choose the supports diameters to the dimensions of the workings. In the roadway, between existing corroded supports, 10 sets of ŁP8 / V29 supports stabilized with WR type stretchers were installed (fig. 14.).

The lining for 5 support sections was made of welded steel mesh, and for the others reinforced concrete lining. Nine newly built frames were covered with three types of shotcrete (fig. 15), whose parameters are summarized in Table 1.

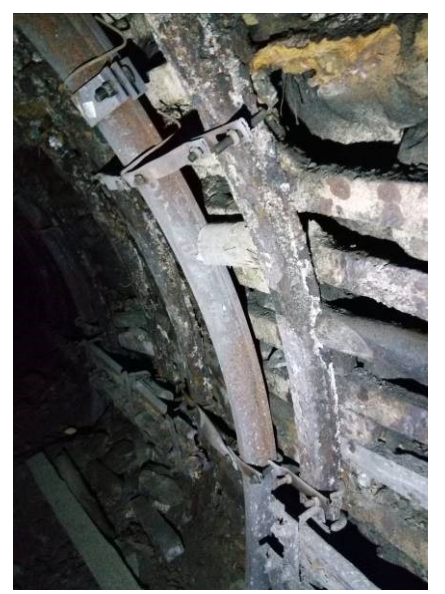

Fig. 14. An example of $€ P 8 / V 29$ steel arch support section(photo P.Ficek).

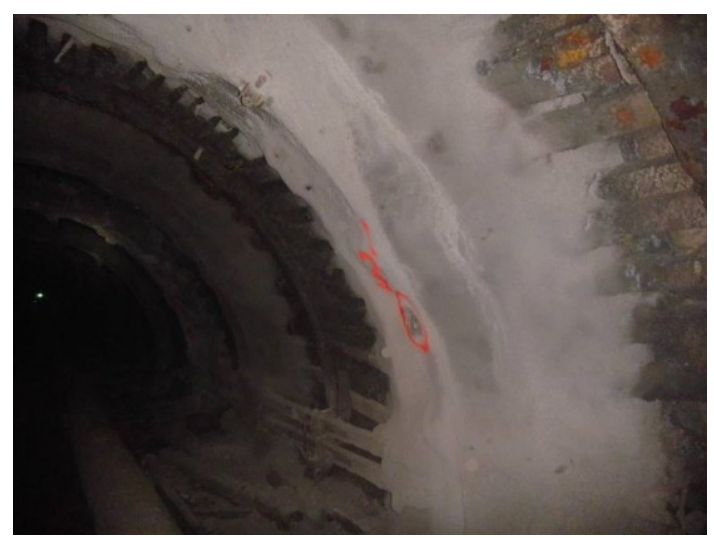

Fig. 15. An ŁP8/V29 steel arch support section covered with shotcrete layer (photo P.Ficek).

Each stand differed in the type of lining, the binder used and its thickness. The characteristics of individual testing stands are presented in Table 2.

However, one support section was not covered with shotcrete. Their load capacity will be a reference for the capacity of the remaining ones, covered with shotcrete. It will also allow the calibration of numerical models in computer simulations of corroded supports.

Determining the load capacity of corroded supports coated with shotcrete is the primary goal of planned tests. The results will allow the selection of optimal parameters of the shotcrete coating for specific cases of corrosion of the supports. 
Table 1. Basic parameters of shotcrete used in underground roadways.

\begin{tabular}{|c|c|c|c|}
\hline No. & Binder & Additional reinforcement & Compressive strength \\
\hline 1 & Cover TW 40 & none & $\mathrm{R}_{\mathrm{c}}>45 \mathrm{MPa}$ \\
\hline 2 & Cover TW 40S & sprayed polymer fibers & $\mathrm{R}_{\mathrm{c}}>50 \mathrm{MPa}$ \\
\hline 3 & Cover Beton C20/25 F & sprayed polymer fibers & $\mathrm{R}_{\mathrm{c}}>30 \mathrm{MPa}$ \\
\hline
\end{tabular}

Table 2. The characteristics of test sites.

\begin{tabular}{|c|c|c|c|}
\hline $\begin{array}{c}\text { No. of } \\
\text { test site }\end{array}$ & Binder type & Applied lining & $\begin{array}{c}\text { Thickness of shotcrete } \\
\text { layer }[\mathbf{c m}]\end{array}$ \\
\hline 1 & Cover TW 40S & Reinforced concrete bars & 20 \\
\hline 2 & Cover TW 40S & Reinforced concrete bars & 30 \\
\hline 3 & Cover Beton C20/25 F & Reinforced concrete bars & 20 \\
\hline 4 & Cover Beton C20/25 F & Reinforced concrete bars & 30 \\
\hline 5 & Cover TW 40S & Steel net & 20 \\
\hline 6 & Cover TW 40S & Steel net & 30 \\
\hline 7 & Cover Beton C20/25 F & Steel net & 20 \\
\hline 8 & Cover Beton C20/25 F & Steel net & 30 \\
\hline 9 & Cover TW & Steel net & 30 \\
\hline
\end{tabular}

\section{Methodology and test equipment}

The research methodology was prepared for efficient research. It was assumed that the support sections will be weighted with forces acting through four chain links towards the workings. Tensometric force sensors were attached to the tendons, and wire displacement sensors connected to the amplifier were attached to the supports.

Recording of signals from sensors was planned in a portable computer. As the weighting system, elements of the powered roof support section were used, equipped with special attachments. The idea of the measurements is shown in Figure 16, while Figure 17 shows the method of weighting the supports.

For proper stabilization of the entire weighting system, additional props were used apart from the tested support sections. The whole system installed in the workings is shown in Figure 18.

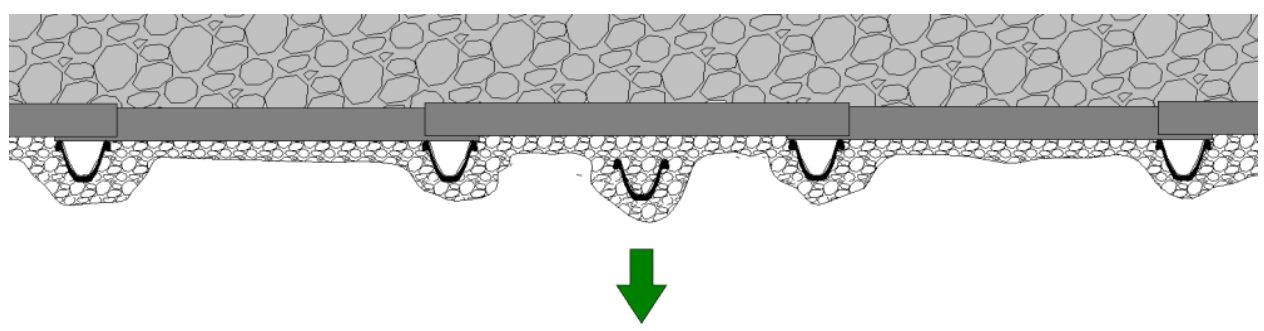

Fig. 16. The idea of studies. 


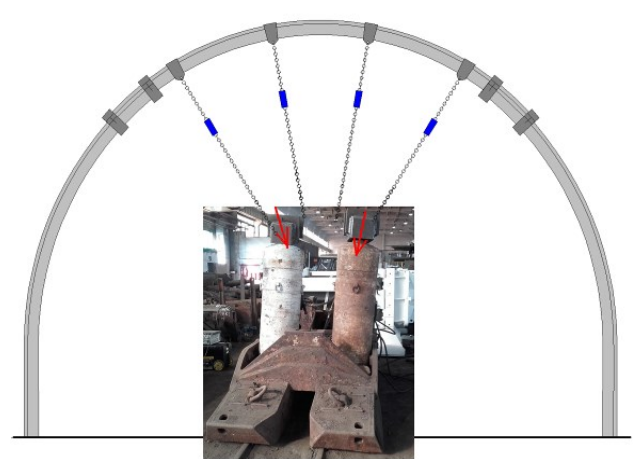

Fig. 17. Scheme of system of weighting steel arch support sections.

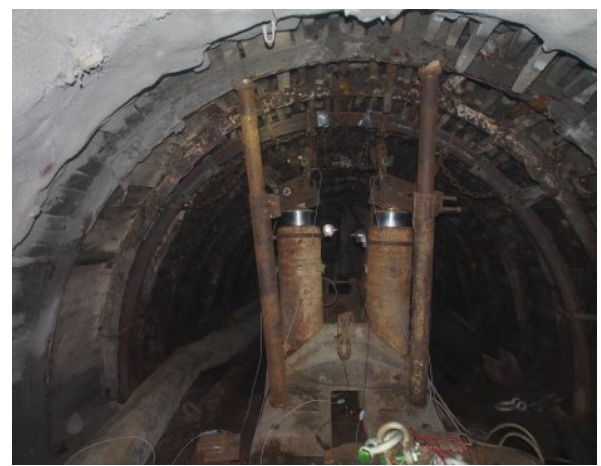

Fig. 18. Testing equipment ready to use installed in testing site (photo P.Ficek).

\section{Summary}

Proper load capacity of mixed underground roadway support - steel arch supports covered with shotcrete layer - is very important for providing stability of underground workings and safety of employees. The importance of this matter increases in case of reinforcing corroded steel arch support sections with shotcrete layer.

The described method of analysis of corroded supports covered with shotcrete allows to define its load capacity taking into account the consolidation of lining and rock filling behind support sections which was omitted in analytic calculations.

This article was created due to the statutory work of The Central Mining Institute GIG no. 143 02028-151 entitled: "Defining the load capacity of corroded steel arch supports covered with shotcrete layer in conditions of underground coal mines"

\section{References}

1. W. Hałat, Nośność odrzwi wybranych obudów lukowych (Bearing capacity of selected steel arch support) Górnictwo i Geoinżynieria 29 (3/1), 247-250 (2005) (in Polish).

2. S. Prusek, M. Rotkegel, J. Stokłosa,A. Malesza, Ocena stopnia skorodowania odrzwi obudowy chodnikowej na przyktadzie ZG „Bytom III” (Assessment of corrosion level of underground roadways support based on an example of $Z G$ "Bytom III") Miesięcznik WUG 9, 13-20 (2004) (in Polish).

3. S. Prusek, M. Rotkegel, Korozja obudowy wyrobisk korytarzowych, (Corrosion of roadways' supports) Wiadomości Górnicze 7-8, Katowice, 336-341 (2005) (in Polish).

4. S. Prusek, S. Rajwa, M. Rotkegel, Obudowa torkretowa $w$ polskich kopalniach węgla kamiennego. Nowe spojrzenie na wybrane zagrożenia naturalne $w$ kopalniach (Shotcrete support in Polish hard coal mines. A fresh look at selected natural hazards in mines) S. Prusek and J. Cygankiewicz eds., Katowice, 131-137 (2012) (in Polish).

5. S. Prusek, M. Rotkegel, Ł. Małecki, Wybrane sposoby wzmacniania skorodowanej stalowej obudowy odrzwiowej (Selected ways of reinforcing the corroded steel arch suport) Przegląd Górniczy 5, 71-77 (2015) (in Polish). 
6. M. Rotkegel, M. Grodzicki, The concept of the modification and analysis of the strength of steel roadway supports for coal mines in the Soma Basin in Turkey, Studia Geotechnica et Mechanica 40(1) 38-45 (2018).

7. R. Horst, M. Modrzik, P. Ficek, M. Rotkegel, A. Pytlik Corroded steel support friction joint load capacity studies as found in Piast-Ziemowit coal mine. 88-94 / Badania nośności skorodowanych złaczy ciernych obudowy odrzwiowej na przykładzie Kopalni Wegla Kamiennego Piast-Ziemowit, MINING - Informatics, Automation and Electrical Engineering, 1, 88-94 (2018).

8. G. G. Litwinskij, G. I. Gajko, N. I. Kyldyrkajew, Stalnyje ramnyje kriepi gornych wyrabotok, Kijew „Technika” (1999).

9. R. D. Cook, D. S. Malkus, M. E. Plesha, R. J. Witt, Concepst and applications of finite element analysis, John Willey \& Sons, Inc. New York (2002).

10. J. Baszkiewicz, M. Kamiński, Podstawy korozji materiałów (Basics of material corrosion) Wyd. Politechnika Warszawska, Warszawa, (1997) (in Polish).

11. Huta Łabędy, Katalog wyrobów dla górnictwa (Catalog of mining products) Gliwice (2017) (in Polish).

12. PN-69/H-04609 - Korozja metali. Terminologia (Metal corrosion. Terminology) (in Polish).

13. PN-78/H-04608 - Korozja metali. Skala odporności metali na korozję (Scale of corrosion resistance of metals.) (in Polish).

14. PN-78/H-04610 - Korozja metali. Metody oceny badań korozyjnych (Assessment methods for corrosion tests.) (in Polish).

15. PN-H-93441-1 - Kształtowniki stalowe walcowane na gorąco dla górnictwa. Ogólne wymagania i badania (Hot rolled steel sections for mining. General requirements and tests) (in Polish).

16. PN-H-93441-3 - Kształtowniki stalowe walcowane na gorąco dla górnictwa. Kształtowniki typu V. Wymiary (Hot rolled steel sections for mining. V-sections. Dimensions) (in Polish).

17. PN-H-84042 - Stale mikrostopowe na kształtowniki i akcesoria górnicze (Microalloy steels for mining sections and accessories) (in Polish).

18. G. Wranglen, Podstawy korozji i ochrony metali (Basics of corrosion and metal protection) Wydawnictwa Naukowo-Techniczne, Warszawa, (1985) (in Polish).

19. S. Duży, P. Głuch, A. Ratajczak, D. Giza, Przyczyny zawałów wyrobisk korytarzowych $i$ wybrane sposoby wzmacniania obudowy (Heading collapses in view of the loss of bearing capacity and the technical wear of support sets) Zeszyty Naukowe IGSMiE PAN 97, 173-188 (2017) (in Polish).

20. J. Wasiuczkow, A. Gonet, J. Siemek, Górnictwo węgla kamiennego w Rosji (Hard coal mining in Russia) Arch. Min. Sci. 50, 227-234 (2005) (in Polish).

21. P. Ficek, A. Rozmus, M. Rotkegel, J. Maślanka, Określenie nośności obudowy wyrobisk korytarzowych $w$ warunkach dolowych (Determination of the bearing capacity of the roadway supports in underground conditions) Cuprum Ore Mining Scientific and Technical Magazine 91(2), 5-14 (2019) (in Polish).

22. PN-G-15022 - Obudowa wyrobisk górniczych. Odrzwia podatne z kształtowników korytkowych. Wymagania wytrzymałościowe i badania (Underground workings support. Susceptible supports made of U sections. Strength requirements and tests) (in Polish).

23. COSMOS/M - User Guide. SRAC (1999). 